JSAP: Journal Syariah and Accounting Public

ISSN: 2622-3538

Available Online at https://journal.umgo.ac.id/index.php/JSAP/index

Vol. 3, No. 1 Juli 2020

DOI: $10.31314 /$ jsap.3.1.1-8.2020

\title{
PENGELOLAAN OBJEK WISATA PENTADIO RESORT DALAM MENINGKATKAN PENDAPATAN ASLI DAERAH DI KABUPATEN GORONTALO
}

\author{
Sakbir \\ Program Studi Akuntansi Fakultas IImu Sosial Universitas Muhammadiyah Gorontalo, \\ Indonesia \\ Email; kenanzanbaqah@Gmail.com
}

Info Artikel: Diterima: 13 Februari 2020, Disetujui: 23 Februari 2020, Publish 15 Juli 2020

\begin{abstract}
:
This research aims to find out the management of pentadio resort attractions. The research method uses a qualitative type. Management of pentadio resort attractions in planning aspects is not optimal. This can be seen from the less planned arrangement of tourist attractions. Management of pentadio resort attractions in the organizing aspect is not optimal. This can be seen from the irregularities of the officers in the work such as the absence of uniformity in dress, and the many facilities that no longer function. Management of pentadio resort attractions in aspects of supervision is not optimal. This can be seen from the many tourist facilities that are not maintained anymore and just left.
\end{abstract}

Keywords: Management of Tourism Objects, Regional Original Revenues

\begin{abstract}
Abstrak:
Penelitian ini bertujuan untuk mengetahui mengetahui pengelolaan objek wisata pentadio resort. Metode penelitian menggunakan jenis kualitatif. Pengelolaan objek wisata pentadio resort dalam aspek perencanaan belum optimal. Hal ini terlihat dari kurang terencananya penataan objek wisata. Pengelolaan objek wisata pentadio resort dalam aspek pengorganisasian belum optimal. Hal ini terlihat dari ketidakteraturan para petugas di dalam bekerja misalnya tidak adanya keseragaman dalam berpakaian, serta banyaknya fasilitas yang tidak lagi berfungsi. Pengelolaan objek wisata pentadio resort dalam aspek pengawasan belum optimal. Hal ini terlihat dari banyaknya fasilitas objek wisata yang tidak terawat lagi dan dibiarkan begitu saja.
\end{abstract}

Kata kunci : Pengelolaan Objek Wisata, Pendapatan Asli Daerah

\section{PENDAHULUAN}

Perubahan paradigma pembangunan

Nasional dari sentralisasi menuju desentralisasi membangkitkan potensi dimana otonomi daerah berkuasa dalam percepatan pertumbuhan daerah. Otonomi daerah dan desentralisasi merupakan jawaban atas permasalahan lokal bangsa
Indonesia berupa ancaman disintegrasi bangsa, kemiskinan, ketidakmerataan pembangunan, rendahnya kualitas hidup masyarakat, dan masalah pembangunan sumber daya manusia (Mardiasmo, 2002). Sektor pariwisata merupakan salah satu sektor pembangunan yang terus digalakkan oleh pemerintah. Hal ini disebabkan karena 
pariwisata mempunyai peran yang sangat penting dalam pembangunan Indonesia khususnya sebagai penghasil devisa negara di samping sektor migas atau menjadi penyumbang terbesar dalam perdagangan internasional dari sektor jasa. Sektor pariwisata dapat dikategorikan kedalam kelompok industri terbesar dimana $8 \%$ ekspor barang dan jasa berasal dari sektor pariwisata. Pengembangan sektor pariwisata merupakan suatu hal yang harus dipertimbangkan secara logis dan realistis (Pitana, 2000;19) Pariwisata adalah salah satu dari industri gaya baru, yang mampu menyediakan pertumbuhan ekonomi yang cepat dalam hal kesempatan kerja, pendapatan, taraf hidup dan dalam mengaktifkan sektor produksi lain di dalam negara penerima wisatawan ( Wahab, 2003 : 5). Berkembangnya pariwisata di suatu daerah akan mendatangkan banyak manfaat bagi masyarakat, yakni secara ekonomis, sosial dan budaya. Namun, jika pengembangannya tidak dipersiapkan dan dikelola dengan baik, justru akan menimbulkan berbagai permasalahan yang menyulitkan atau bahkan merugikan masyarakat. Untuk menjamin supaya pariwisata dapat berkembang secara baik dan berkelanjutan serta mendatangkan manfaat bagi manusia dan meminimalisasi dampak negatif yang mungkin timbul maka pengembangan pariwisata perlu didahului dengan kajian yang mendalam, yakni dengan melakukan penelitian terhadap semua sumber daya pendukungnya (Wardiyanta, 2006 : 47). Dari sudut sosial, kegiatan pariwisata akan memperluas kesempatan tenaga kerja baik dari kegiatan pembangunan sarana dan prasarana maupun dari berbagai sektor usaha yang langsung maupun yang tidak langsung berkaitan dengan kepariwisataan. Pariwisata akan dapat menumbuhkan dan meningkatkan pengenalan dan cinta terhadap tanah airnya, sehingga dapat memotifasi sikap toleransi dalam pergaulan yang merupakan kekuatan dalam pembangunan bangsa, selain itu juga pariwisata mampu memperluas cakrawala pandangan pribadi terhadap nilai-nilai kehidupan.

Dari sudut ekonomi bahwa kegiatan pariwisata dapat memberikan sumbangan terhadap penerimaan daerah bersumber dari pajak, retribusi parkir dan karcis atau dapat mendatangkan devisa dari para wisatawan mancanegara yang berkunjung. Adanya pariwisata juga akan menumbuhkan usahausaha ekonomi yang saling merangkai dan menunjang kegiatannya sehingga dapat meningkatkan pendapatan masyarakat. Indonesia sebagai Negara kepulauan terbesar di dunia memiliki banyak potensi wisata yang jika digali secara maksimal maka akan membangun bangsa ini lebih maju lagi. Tidak terkecuali Kabupaten Gorontalo yang merupakan salah satu daerah yang ada di Provinsi Gorontalo, dimana Kabupaten Gorontalo memiliki berbagai macam obyek wisata diantaranya wisata alam, wisata buatan, dan wisata sejarah yang apabila dikelola dan dikembangkan dengan baik dan tepat maka akan menjadi daerah tujuan wisata yang menarik untuk dikunjungi. Selain itu, dengan meningkatnya wisatawan yang berkunjung maka secara langsung akan menambah Pendapatan Asli Daerah (PAD) dan pendapatan masyarakat sekitar objek wisata.

Salah satu objek wisata yang ada di Kabupaten Gorontalo adalah Pentadio Resort yang merupakan salah satu lokasi objek wisata bertaraf internasional di Kecamatan Telagabiru, Kabupaten Gorontalo. Di kawasan Pentadio Resort ini para pengunjung dapat menikmati siraman 
air dari sumber mata air yang cukup hangat yang bermanfaat untuk menyembuhkan penyakit kulit. Di samping itu, kawasan ini juga dilengkapi berbagai macam fasilitas yang bertaraf internasional dan dikelola secara profesional, sehingga para pengunjung dapat melakukan aktivitas santai lainnya dengan nyaman, seperti mandi uap, mandi celup, berenang di kolam renang air panas atau di kolam renang air dingin, memancing, dan bersepeda air. Bagi pengunjung yang ingin menyalurkan hobi menyanyi, di lokasi ini juga tersedia pub dan karaoke.

Pada awalnya, obyek wisata seluas 14 hektar ini telah diresmikan oleh Pemerintah Belanda sejak tahun 1928, yang ditandai dengan sebuah batu peringatan di sekitar pemandian air panas di kawasan obyek wisata ini. Sejak itu, masyarakat setempat menjadikan tempat ini sebagai saran rekreasi dan menyembuhkan berbagai macam penyakit. Lalu pada tanggal 25 Fabruari 2004, obyek wisata ini di resmikan oleh Menteri Koordinator Kesejahteraan Rakyat (Menkokesra) saat itu, Jusuf Kalla yang saat ini menjabat sebagai Waki Presiden RI. Pentadio Resort sendiri terus mengalami perbaikan dan pengembangan guna menarik minat masyarakat baik dari dalam maupun masyarakat dari luar untuk berkunjung menikmati segala kenyamanan dan layanan yang disajikan oleh pengelola.

Fakta hingga hari ini, bahwa sumbangan pentadio resort terhadap Peningkatan Pendapatan Asli Daerah (PAD) belum seperti yang diharapkan.

Lebih besar pasak dari pada tiang, adalah sebuah pepatah yang penulis coba gambarkan tentang situasi yang terjadi di pentadio resort. Pengelolaan objek wisata yang baik akan memberikan dampak positif secara social ekonomi, baik untuk pemerintah maupun bagi masyarakat disekitar lokasi wisata tetapi jika terjadi sebaliknya maka akan berdampak pada pengurasan dana APBD semata tanpa memberikan keuntungan.

Hasil obseervasi sementara penulis menunjukkan bahwa, pengelolaan objek wisata pentadio resort belum optimal dalam meningkatkan Peningkatan Pendapatan Asli (PAD) Daerah Kabupaten Gorontalo. Hal ini diungkapkan oleh salah seorang petugas dalam sesi wawancara awal peneliti yang mengatakan bahwa;

"Pemerintah Kabupaten sebagai pengelola objek wisata pentadio resort saat ini terus berupaya untuk menarik para pengunjung berwisata. Dalam pengelolaannya masih terdapat kekurangan dan kelemahan seperti pengelolaan potensi sumber mata air panas". (Wawancara dengan pengelola/petugas objek wisata pentadio resort).

Hal ini terlihat dari proses perencanaan pengembangan objek wisata yang kurang terarah. Beberapa pengunjung mengeluhkan kurangnya daya tarik obyek wisata pentadio resort seperti penataan ruang atau tempat dan minimnya sarana dan prasarana sebagai fasilitas penunjang. Dengan kata lain, pengelola objek wisata pentadio resort belum mampu membuat rencana yang selaras dengan keinginan masyarakat sebagai subjek atau penikmat objek wisata.

Selanjutnya, pengelola juga kurang maksimal dalam melakukan pengorganisasian baik pada aspek sumber daya manusia maupun aspek sumber daya fisik. Di dalam area objek wisata pentadio resort, hampir tidak dapat dibedakan antara pengunjung dan petugas objek wisata dikarenakan petugas objek wisata tidak menggunakan seragam yang dapat mempermudah masyarakat atau pengunjung jika kiranya dibutuhkan sesuatu. Pada aspek 
sumber daya fisik juga tidak bisa dimaksimalkan sepeti ari panas yang sudah menjadi ikon. Sejauh ini sumber air panas yang dimiliki oleh objek wisata pentadio resort identik dengan orang berpenyakit. Hal ini membangun dikotomi pengunjung bahwa lokasi kolam air panas khusus orang-orang tua dan memiliki penyakit sehingga bisa dipastikan bahwa potensi permandian air panas tersebut tidak bisa dinikmati masyarakat umum.

Terakhir yang menjadi permasalahan dalam pengelolaan tersebut adalah lemahnya kegiatan pengawasan yang dilakukan oleh pemerintah atau dalam hal ini Dinas Pariwisata Kabupaten Gorontalo. Pengawasan yang sekiranya memberikan evaluasi agar dapat mengeliminir kesalahan dan kekurangan, nyatanya belum terlihat dalam pengelolaan objek wisata pentadio resort.

Beberapa penelitian tentang pengelolaan objek wisata telah dilakukan, namun yang menjadi pembeda dalam penelitian ini adalah fokus dan lokasi penelitian, dimana dalam penelitian ini difokuskan pada pengelolaan objek wisata yang berdampak pada peningkatkan pendapatan asli daerah. Adapun lokasi penelitian, dilaksanakan di objek wisata pentadio resort yang berada di wilayah Kabupaten Gorontalo.

Adapun tujuan dari penelitian ini adalah untuk mengetahui pengelolaan objek wisata Pentadio Resort dalam meningkatkan Pendapatan Asli Daerah (PAD) di Kabupaten Gorontalo.

\section{METODE PENELITIAN}

Pelaksanaan penelitian ini menggunakan pendekatan kualitatif. Dengan melihat penggunaan pendekatan dan jenis penelitian dalam penelitian ini, maka adapun kehadiran peneliti yaitu sebagai instrumen utama yang harus berbaur dengan lingkungan penelitian. Dalam hal ini, peneliti langsung menelaah dan menganalisa sumber data terkait dengan permasalahan penelitian sehingga hasil penyusunan penelitian nantinya akan menjadi akurat. Kehadiran peneliti sendiri dilokasi penelitian diawali dengan melakukan rancangan penelitian dan melakukan pemilihan lokasi sebagai objek sebagai lokus yang memiliki permasalahan.

\section{HASIL DAN PEMBAHASAN}

Berikut uraian pembahasan terkait dengan pengelolaan objek wisata pentadio resort dalam meningkatkan Pendapatan Asli Daerah (PAD) di Kabupaten Gorontalo.

\section{Aspek perencanaan dalam pengelolaan objek wisata pentadio resort}

Dinas Kepemudaan, Olahraga dan Pariwisata Kabupaten Gorontalo merupakan Dinas yang berwenang untuk mengelola objek wisata yang ada di Kabupaten Gorontalo, termasuk objek wisata pentadio resort. Tujuan dari pengelolaan ini adalah dalam rangka peningkatan Pendapatan Asli Daerah (PAD) mengingat potensi yang dimiliki oleh Kabupaten Gorontalo dalam hal pariwisata cukup menjanjikan. Olehnya itu, dalam memaksimalkan potensi yang ada, maka pihak pengelola harus mampu membuat perencanaan yang baik.

Perencanaan sendiri adalah suatu proses menentukan apa yang ingin dicapai di masa yang akan datang serta menetapkan tahapan-tahapan yang dibutuhkan untuk mencapainya. Sebagian kalangan berpendapat bahwa perencanaan adalah suatu aktivitas yang dibatasi oleh lingkup waktu tertentu, sehingga perencanaan, lebih jauh diartikan sebagai kegiatan terkoordinasi untuk mencapai suatu tujuan tertentu dalam waktu tertentu. Artinya perencanaan adalah suatu proses 
menentukan apa yang ingin dicapai di masa yang akan dating serta menetapkan tahapan-tahapan yang dibutuhkan untuk mencapainya. Dengan demikian, proses perencanaan dilakukan dengan menguji berbagai arah pencapaian serta mengkaji berbagai ketidakpastian yang ada, mengukur kemampuan (kapasitas) kita untuk mencapainya kemudian memilih arah-arah terbaik serta memilih langkah-langkah untuk mencapainya" (Komarudin).

Dalam penelitian ini, yang dimaksud dengan perencanaan adalah suatu kegiatan yang awal yang dilakukan oleh pemerintah Kabupaten Gorontao atau dalam hal ini adalah Dinas Kepemudaan, Olahraga dan Pariwisata Kabupaten Gorontalo dalam upaya mengembangkan salah satu objek wisata yang dimilikinya yakni pentadio resort guna meningkatkan Pendapatan Asli Daerah (PAD) Kabupaten Gorontalo. Berdasarkan hasil penelitian dan analisis penulis dapat diketahui bahwa, pengelolaan objek wisata pentadio resort dalam aspek perencanaan belum optimal. Hal ini terlihat dari kurang terencananya penataan objek wisata khususnya dalam memaksimalkan potensi objek wisata air panas. Sejauh ini, potensi air panas sebagai potensi andalan, justru hanya bisa dinikmati oleh segelintir orang saja seperti orang tua atau orang sakit.

\section{Aspek pengorganisasian dalam} pengelolaan objek wisata pentadio resort

Obyek dan daya tarik wisata adalah segala sesuatu yang memiliki keunikan, keindahan, dan nilai yang berupa keanekaragaman kekayaan alam, budaya dan hasil buatan manusia yang menjadi sasaran atau tujuan kunjungan wisatawan dan daerah tujuan pariwisata uang selanjutnya disebut Destinasi Pariwisata adalah kawasan geografis yang berada dalam satu atau lebih wilayah admnistratif yang didalamnya terdapat daya tarik wisata, fasilitas umum, fasilitas pariwisata, aksessibilitas serta masyarakat yang saling terkait dan melengkapi terwujudnya kepariwisataan. ( UU No 10 tahun 2009 tentang kepariwisataan).

Untuk mengintegrasikan kesemua unsur tersebut maka pemerinta sebagai pihak yang memiliki kewenangan diharapkan dapat melakukan pengorgansasian. Dalam kaitannya dengan tujuan pemerintah dalam rangka meningkatkan Pendapatan Asli Daerah (PAD), fungsi pengorganisasian merupakan salah satu kunci dalam mengelola objek wisata.

Pengorganisasian adalah merupakan fungsi kedua dalam Manajemen dan pengorganisasian didefinisikan sebagai proses kegiatan penyusunan struktur organisasi sesuai dengan tujuan-tujuan, sumber-sumber, dan lingkungannya. Dengan demikian hasil pengorganisasian adalah struktur organisasi. Pengorganisasian (Organizing) adalah suatu langkah untuk menetapkan, menggolongkan dan mengatur berbagai macam kegiatan yang di pandang. Seperti bentuk fisik yang tepat bagi suatu ruangan kerja administrasi, ruangan laboratorium, serta penetapan tugas dan wewenang seseorang pendelegasian wewenang dan seterusnya dalam rangka untuk mencapai tujuan (Basu Swasta)

Dalam penelitian ini, yang dimaksud dengan pengorganisasian adalah suatu kegiatan pengaturan pada sumber daya manusia dan sumber daya fisik lain yang dimiliki oleh pentadio resort untuk menjalankan rencana yang telah ditetapkan serta menggapai tujuan organisasi yakni guna meningkatkan Pendapatan Asli Daerah (PAD) Kabupaten Gorontalo. Berdasarkan hasil penelitian dan analisis penulis dapat diketahui bahwa, pengelolaan objek wisata pentadio resort dalam aspek 
pengorganisasian belum optimal. Hal ini terlihat dari ketidakteraturan para petugas di dalam bekerja misalnya tidak adanya keseragaman dalam berpakaian, kurangnya kedisiplinan para petugas serta banyaknya fasilitas yang tidak lagi berfungsi sebagai mana msetinya.

\section{Aspek pengawasan dalam pengelolaan objek wisata pentadio resort}

Obyek-obyek wisata unggulan di Provinsi Gorontalo memiliki potensi wisata yang menarik untuk dikunjungi wisatawan sehingga sangat terbuka peluang untuk dapat meningkatkan Pendapatan Asli Daerah (PAD), termasuk Kabupaten Gorontalo dengan segala sumber daya alamnya yang mampu memanjakan para pelancong ataupun wisatawan baik wisatawan dari luar maupun dari dalam negeri sendiri. Oleh karena itu pemerintah daerah dalam rangka memaksimalkan potensi yang ada, juga harus mengawal pelaksanaannya sehingga tujuan dan citacitanya yaitu meningkatkan Pendapatan Asli Daerah (PAD) bisa tercapai.

Pengawasan adalah suatu upaya yang sistematik untuk menetapkan kinerja standar pada perencanaan untuk merancang sistem umpan balik informasi, untuk membandingkan kinerja aktual dengan standar yang telah ditentukan, untuk menetapkan apakah telah terjadi suatu penyimpangan tersebut, serta untuk mengambil tindakan perbaikan yang diperlukan untuk menjamin bahwa semua sumber daya perusahaan atau pemerintahan telah digunakan seefektif dan seefisien mungkin guna mencapai tujuan perusahaan atau pemerintahan. Dari beberapa pendapat tersebut diatas dapat ditarik kesimpulan bahwa pengawasan merupakan hal penting dalam menjalankan suatu perencanaan. Dengan adanya pengawasan maka perencanaan yang diharapkan oleh manajemen dapat terpenuhi dan berjalan dengan baik.

Pengawasan pada dasarnya diarahkan sepenuhnya untuk menghindari adanya kemungkinan penyelewengan atau penyimpangan atas tujuan yang akan dicapai. melalui pengawasan diharapkan dapat membantu melaksanakan kebijakan yang telah ditetapkan untuk mencapai tujuan yang telah direncanakan secara efektif dan efisien. Bahkan, melalui pengawasan tercipta suatu aktivitas yang berkaitan erat dengan penentuan atau evaluasi mengenai sejauhmana pelaksanaan kerja sudah dilaksanakan. Pengawasan juga dapat mendeteksi sejauhmana kebijakan pimpinan dijalankan dan sampai sejauhmana penyimpangan yang terjadi dalam pelaksanaan kerja tersebut (Winardi)

Demikian halnya dalam penelitian ini, bahwa yang dimaksudkan dengan pengawasan ialah suatu aktivitas dari pemerintah daerah dalam hal ini Dinas Pariwisata untuk menilai kinerja para pengelola objek wisata pentadio resort berdasarkan standar yang telah dibuat untuk kemudian dibuat perubahan atau perbaikan jika diperlukan. Berdasarkan hasil penelitian dan analisis penulis dapat diketahui bahwa, pengelolaan objek wisata pentadio resort dalam aspek pengawasan belum optimal. Hal ini terlihat dari banyaknya fasilitas objek wisata yang tidak terawatt lagi dan dibiarkan begitu saja serta penyalahgunaan fasilitas seperti kamar atau penginapan. Selain itu ada penyimpangan yang dilakukan oleh beberapa oknum dalam mengelola uang retribusi.

Menurut (Desseler, 2001) dalam ilmu manejemen, fungsi perencanaan, pengorganisasian, dan pengawasan adalah upaya menetapkan tujuan-tujuan dan rancangan tindakan, membangun peraturanperaturan dan prosedur, dan 
memperhitungkan hasil-hasil yang akan terjadi dimana yang akan datang. Lebih lanjut (Desseler, 2001) mengemukakan bahwa alasan diperlukannya ketiga fungsi tersebut dalam manajemen; (1) Tujuan menjadi jelas dan terarah Perencanaan sebagai langkah awal dari pencapaian tujuan akan memberikan arah dan kejelasan tujuan tersebut, sehingga semua komponen ataupun elemen-elemen dalam organisasi mengetahui dengan baik tujuan yang hendak dicapai. (2) Semua bagian yang ada dalam organisasi akan bekerja ke arah satu tujuan yang sama Ketika semua elemen atau bagian dalam organisasi mengetahui tujuan organisasinya dengan jelas dan benar, maka mereka akan bekerja ke satu arah yang sama. Artinya mereka memahami prosedur apa saja yang akan dilakukan sebagaimana yang telah mereka sepakati dalam perencanaan. (3) Menolong mengidentifikasikan berbagai hambatan dan peluang Dengan adanya perencanaan maka organisasi mampu mengidentifikasi berbagai hambatan dan peluang yang ada di lingkungan luar organisasi. Adanya hambatan dan peluang yang datang akan menuntut organisasi mempersiapkan tindakan-tindakan antisipasi ke depan sehingga mereka tetap berada di lajur menuju tujuan awal. (4) Membantu pekerjaan menjadi lebih efisien dan efektif Perencanaan memberikan pandangan bagi organisasi mengenai tindakan apa saja yang harus mereka lakukan demi tercapainya tujuan, termasuk di dalamnya biaya dan lamanya waktu yang dibutuhkan sehingga tujuan terealisasi. Hal ini akan membantu organisasi menjadi lebih efektif dan efisien dalam mencapai tujuan. (5) Perencanaan sendiri dapat diartikan aktivitas pengawasan Ketika prosedur kerja sudah ada dan jelas, tentu hal ini menjadi sebuah control terhadap pelaksanaan di lapangan. Artinya mereka akan bekerja sesuai prosedur sebab perencanaan sebagai pengawasan. (6) Perencanaan juga membantu untuk mengurangi resiko dan ketidakpastian Dalam mencapai sebuah tujuan, terdapat berbagai macam resiko dan ketidakpastian yang akan menghadang dalam pencapaian tujuan organisasi. Oleh karena itu, adanya perencanaan akan memperjelas tindakantindakan dan prosedur kerja sehingga ketidakpastian tersebut dapat diminimalisir.

\section{KESIMPULAN}

Berdasarkan hasil penelitian dan pembahasan, maka selanjutnya dilkemukakan hasil kesimpulan peneliti, sebagai berikut; Pengelolaan objek wisata pentadio resort dalam aspek perencanaan belum optimal. Hal ini terlihat dari kurang terencananya penataan objek wisata khususnya dalam memaksimalkan potensi objek wisata air panas. Sejauh ini, potensi air panas sebagai potensi andalan, justru hanya bisa dinikmati oleh segelintir orang saja seperti orang tua atau orang sakit. Pengelolaan objek wisata pentadio resort dalam aspek pengorganisasian belum optimal. Hal ini terlihat dari ketidakteraturan para petugas di dalam bekerja misalnya tidak adanya keseragaman dalam berpakaian, kurangnya kedisiplinan para petugas serta banyaknya fasilitas yang tidak lagi berfungsi sebagai mana msetinya. Pengelolaan objek wisata pentadio resort dalam aspek pengawasan belum optimal. Hal ini terlihat dari banyaknya fasilitas objek wisata yang tidak terawatt lagi dan dibiarkan begitu saja serta penyalahgunaan fasilitas seperti kamar atau penginapan. Selain itu ada penyimpangan yang dilakukan oleh beberapa oknum dalam mengelola uang retribusi. 


\section{SARAN}

Berdasarkan hasil penelitian dan kesimpulan di atas, maka berikut saran yang peneliti tawarkan sebagai bahan pertimbangan;

1. Perlunya dilakukan upaya perbaikan dan penambahan fasilitas objek wisata yang terencana dengan baik dengan mempertimbangkan kesesuaian anggaran dan selera para pengunjung.

2. Perlunya dilakukan upaya pengorganisasian baik dari sumber daya manusia maupun sumber daya fisik yang dimiliki oleh objek wisata pentadio resort sehingga dapat lebih optimal di dalam memberikan pelayanan kepada pengunjung.

Perlunya meningkatkan fungsi pengawasan pemerintah daerah terhadap aktivitas objek wisata pentadio resort khususnya dalam hal pengelolaan dana retribusi dengan melakukan pembaharuan sistem dalam rangka mencegah terjadinya penyelewengan dana retribusi.

\section{REFERENS}

Athoillah, Anton, (2010). Dasar-dasar Manajemen. Bandung: C.V Pustaka Setia

Bangun Wilson, (2008). Manajemen Sumber Daya Manusia, Erlangga, Bandung.

BPS Kabupaten Gorontalo. (2011-2014). Gorontalo Dalam Angka. Gorontalo
Burkart, A. J. dan Medlik, S. (1981). Tourism: Past, Present and Future. London: Heinemann.

Fathoni Abdurrahmat, (2009). " Organisasi dan Manajemen Sumber Daya Manusia" Jakarta : Rineka Cipta

Griffin, Ricky W, (2007). Manajemen; edisi ketujuh jilid 2. Jakarta: Erlangga.

Hamalik, Oemar, (2007). Manajemen Pengembangan Kurikulum, Bandung: PT. Remaja Rosda Karya.

Lituhayu, Heri. (2011). Strategi Pengembangan Pariwisata Kabupaten Pati. Universitas Diponegoro

Moekijat, (2011); "Kamus Manajemen", Bandung: Mandar Maju, Edisi Kelima.

Oka, A. Yoeti. (2005). Perencanaan Strategis Pemasaran Daerah Tujuan Wisata. Jakarta : Pradnya Paramita

Pendit, Nyoman. (2002). Ilmu Pariwisata : Sebuah Pengantar Perdana. Jakarta : PT Pradnya Paramiata

Prajudi., Dr., Mr., (2011). Administrasi Manajemen Umum, Jakarta: CV Mas Haji

Ross, Glenn F. (1998). Psikologi Pariwisata.Jakarta : Yayasan Obor Indonesia

Rosyidi, (2007). Organisasi dan Manajemen. Yogyakarta : PT. Bentang Pustaka

Sammeng, Andi Mappi. (2001). Cakrawala Pariwisata. Jakarta : Balai Pustaka

Siagian, Sondang P. (2010). Filsafat Administrasi. Jakarta : Gunung Agung.

Sihotang. (2007). Manajemen Sumber Daya Manusia. 